\title{
Descending Aorta Thrombus in a Neonate Mimicking Coarctation of the Aorta: Mechanical Thrombectomy using the AngioJet ${ }^{\circledR}$ Catheter
}

\author{
Jennifer F. Gerardin, ${ }^{1} \mathrm{MD}$, Cindy S. Anderson, ${ }^{1} \mathrm{MD}$, Aimee K. Armstrong, ${ }^{2} \mathrm{MD}$, \\ and Ronald G. Grifka, ${ }^{2 \star} \mathrm{MD}$

\begin{abstract}
A 5-day-old neonate presented in shock, with signs and symptoms of severe coarctation of the aorta. He was diagnosed with a patent aortic arch, and a completely thrombosed abdominal aorta. The authors report the successful transcatheter removal of the entire thrombus using the AngioJet ${ }^{\circledR}$ Thrombectomy system. This represents the first published use of the AngioJet ${ }^{\mathbb{B}}$ catheter in the aorta of a pediatric patient. $\odot 2012$ Wiley Periodicals, Inc.
\end{abstract}

Key words: AngioJet; thrombectomy; transcatheter; coarctation

\section{INTRODUCTION}

Intravascular thrombosis is rare in neonates. When a thrombus does occur, it is usually a venous thrombus [1]. If an arterial thrombus occurs, it is often associated with an indwelling arterial catheter. If a neonate develops a thrombus in the abdominal aorta, it is almost always related to an umbilical artery catheter (UAC) [2]. Depending on the size of the aortic thrombus, the infant may be asymptomatic or may display signs and symptoms of coarctation of the aorta [3]. In reported cases of large abdominal aortic thrombus, decreased lower extremity perfusion was noted in $100 \%$ of patients; acute renal failure, congestive heart failure, and upper extremity hypertension were noted in greater than $40 \%$ of patients [4]. Various treatments have been used, ranging from medical anticoagulation or thrombolytic agents to surgical thrombectomy. In this report, a neonate, who never had a UAC, presented with signs and symptoms of severe coarctation of the aorta. Evaluation revealed a large thrombus that was completely occluding the descending abdominal aorta. Treatment was complicated due to intracranial hemorrhages. To our knowledge, this is the first report of catheter-based mechanical thrombectomy in a neonate with a large aortic thrombus.

\section{CASE REPORT}

A male infant, born at term weighing $3.2 \mathrm{~kg}$, had an uncomplicated neonatal course. He was discharged home on the second day of life. Over the next $48 \mathrm{~h}$, he fed poorly, had decreased urine output, and developed cyanotic and cold lower extremities. He was brought to the Emergency Department. Upon arrival, he had ago- nal respirations and upper extremity hypertension. He had a normal heart rate, no murmur, normal brachial pulses, absent femoral pulses, hepatomegaly, and no obvious focal neurological deficits.

He was emergently intubated. Laboratory studies revealed hyperkalemia, acidosis, and renal failure. An echocardiogram displayed left ventricular enlargement with global severely depressed systolic function (shortening fraction 16\%), a patent aortic arch, no PDA, absent blood flow in the abdominal descending aorta, and an echo-dense mass completely occluding the abdominal aorta. An abdominal ultrasound characterized the mass as an extensive thrombus in the midupper abdominal aorta, with no blood flow in the renal arteries or mesenteric arteries. A cranial-ultrasound revealed hemorrhagic venous infarcts of both thalami, bilateral grade III intraventricular hemorrhages, and the suggestion of a sagittal sinus thrombus.

${ }^{1}$ Helen DeVos Childrens Hospital, Grand Rapids, Michigan ${ }^{2}$ C.S. Mott Children's Hospital, University of Michigan Congenital Heart Center, Ann Arbor, Michigan

Conflict of interest: Nothing to report.

*Correspondence to: Ronald G. Grifka, MD, C.S. Mott Children's Hospital, University Of Michigan Congenital Heart Center Floor 11, 1540 E. Hospital Drive, Ann Arbor, MI 48109-4204.

E-mail: rgrifka@med.umich.edu

Received 21 December 2011; Revision accepted 18 March 2012

DOI 10.1002/ccd.24435

Published online 2 May 2012 in Wiley Online Library (wileyonlinelibrary.com) 


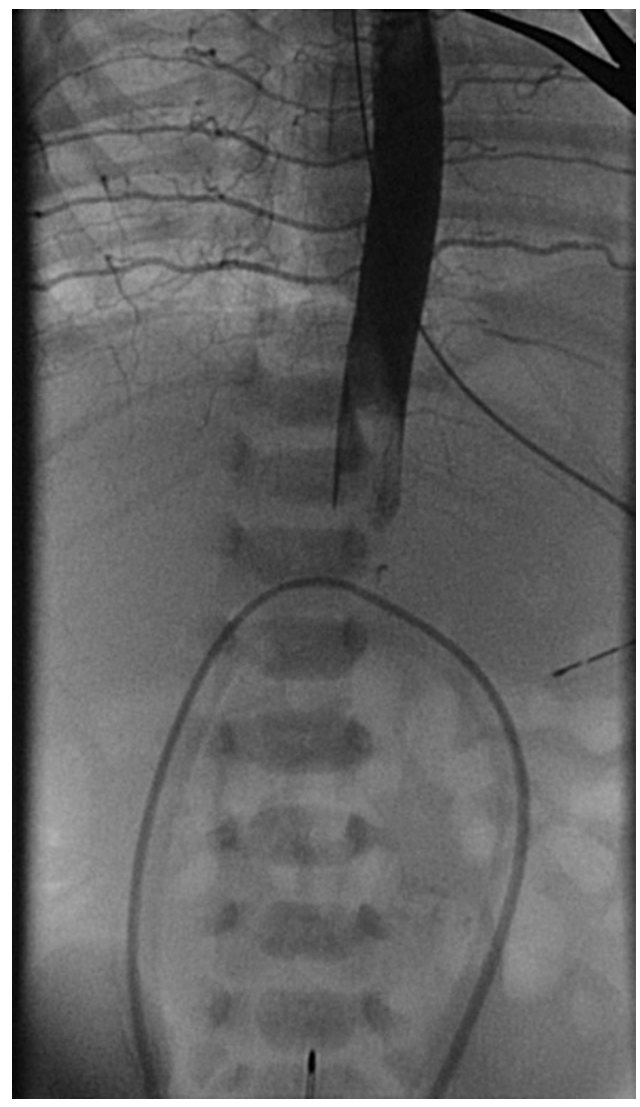

Fig. 1. The multipurpose catheter was advanced through the right-carotid artery sheath and positioned in the descending aorta. Angiography displayed a patent aorta to the level of the diaphragm, with thrombus completely occluding the abdominal aorta.

Family history revealed that the father and paternal grandfather had a clotting disorder. Additional laboratory studies on the neonate revealed: antithrombin III activity 37\% (nl 80-120), protein C activity 12\% (nl $75-125$ ), protein S activity 5\% (nl 60-150). Due to the intracranial hemorrhages and multisystem organ failure, he was not a candidate for thrombolytic therapy or surgical thrombectomy. Catheter-based mechanical thrombectomy was the only therapeutic option.

Because of the neonate's small size and absent femoral pulses, arterial access was obtained through a right-carotid artery cutdown to place a 6-Fr sheath. Using a 4-Fr multipurpose catheter, an angiogram was performed in the descending aorta, revealing complete occlusion of the aorta below the level of the diaphragm (Fig. 1). A 0.035-inch hydrophilic Glide wire (Terumo Medical, Somerset, NJ) was carefully advanced through the thrombus, to the aortic bifurcation, and the catheter advanced easily over the wire. The Glidewire was exchanged for a 0.014" Mailman wire (Boston Scientific, Natick, MA), then the multipurpose catheter was exchanged for a 4-Fr AngioJet ${ }^{\circledR} \mathrm{XMI}^{\circledR}$ catheter

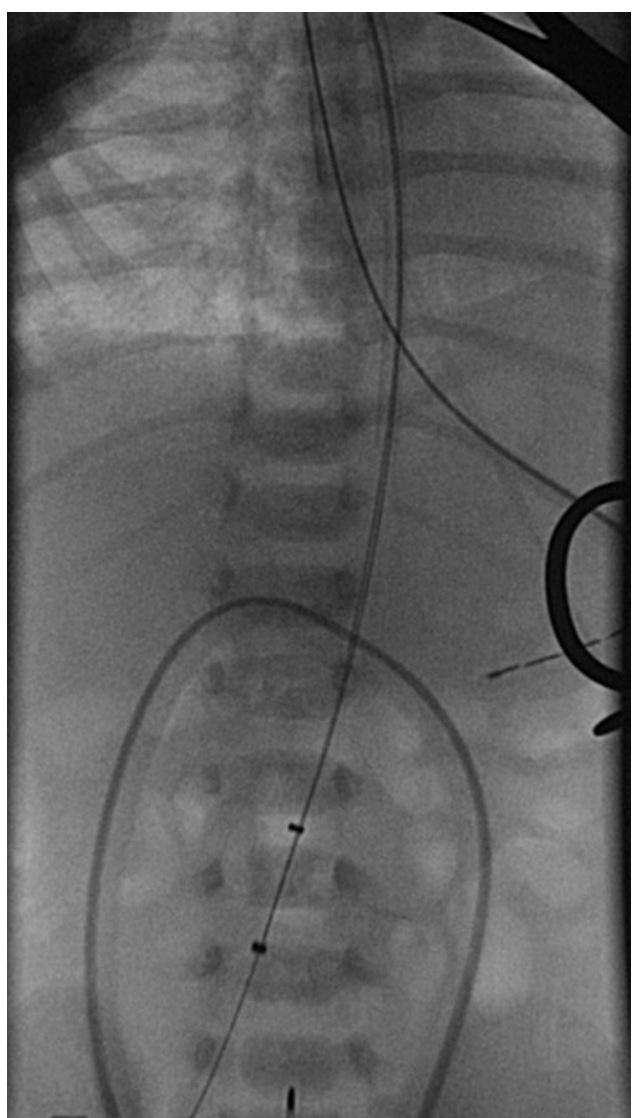

Fig. 2. The AngioJet catheter was advanced over the guidewire, into the thrombus. The AngioJet catheter was passed several times through the thrombus.

(Medrad, Warrendale, PA). The AngioJet ${ }^{\circledR}$ catheter was advanced four times through the thrombus to the aortic bifurcation, then back to the diaphragm; each catheter pass lasting approximately $40 \mathrm{~s}$ (Fig. 2). The catheter removed $20 \mathrm{ml}$ of thrombus and blood. Near the completion of each pass of the AngioJet ${ }^{\circledR}$ catheter, the patient slowly developed bradycardia, from a baseline of $180 / \mathrm{min}$ to $70 / \mathrm{min}$. The AngioJet ${ }^{\circledR}$ catheter was stopped, and over $60 \mathrm{~s}$, the heart rate returned to baseline. The 4-Fr AngioJet ${ }^{\circledR}$ catheter was removed. A repeat angiogram displayed minimal patency of the descending aorta, and no flow into any branches (Fig. 3). The patient received a $15-\mathrm{ml}$ packed red blood cell transfusion. To achieve better thrombolysis, a 6-Fr AngioJet $^{\circledR}$ XPEEDIOR $^{\circledR}$ catheter was advanced over the wire, performing five passes through the abdominal aorta, along with manipulating the distal wire tip to allow catheter passage into both common iliac arteries. The system removed another $35 \mathrm{ml}$ thrombus and blood. With each pass of the 6-Fr AngioJet ${ }^{\circledR}$ catheter, bradycardia developed, and resolved spontaneously after $60 \mathrm{~s}$. A repeat angiogram displayed complete patency of the descending aorta and common iliac arteries, with flow to 


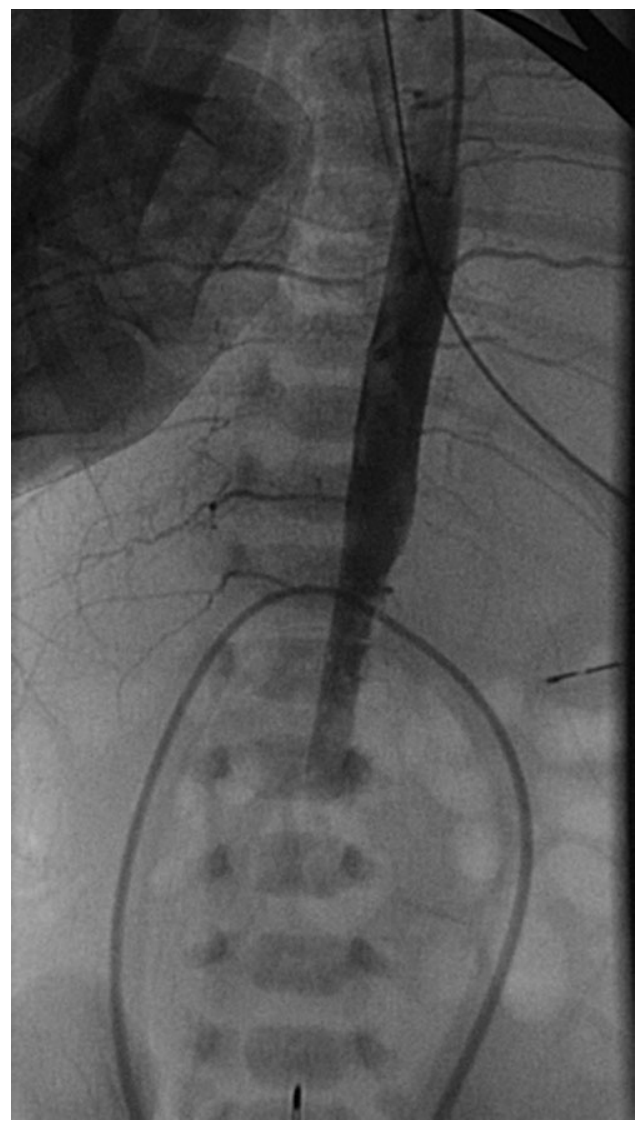

Fig. 3. After thrombectomy using the 4-Fr AngioJet catheter, repeat angiography was performed. Some aortic thrombus was removed, although the distal aorta remained occluded with no flow into the aortic branches.

the superior mesenteric and left renal artery (Fig. 4). A 25-ml packed red blood cell transfusion was administered, followed by calcium chloride. The carotid-artery sheath was removed and the artery was repaired. The patient was transferred back to the pediatric intensive care unit in stable condition.

A repeat echocardiogram demonstrated normal left ventricle size, hyperdynamic systolic function (shortening fraction $51 \%$ ), and a widely patent thoracic and abdominal aorta with pulsatile flow. He began to produce urine. Over the next $24 \mathrm{~h}$, he remained hemodynamically stable with improved urine output. However, the multi-organ system insult progressed. A repeat cranial ultrasound displayed progressive venous thrombosis, extensive hemorrhagic venous infarction of both thalami, and progressive intraventricular hemorrhages. Due to these progressive neurologic findings, life supportive measures were withdrawn. An autopsy revealed extensive vascular thrombi of varying duration, involving the brain and major arteries, however, the abdominal aorta remained patent. Subsequent laboratory testing

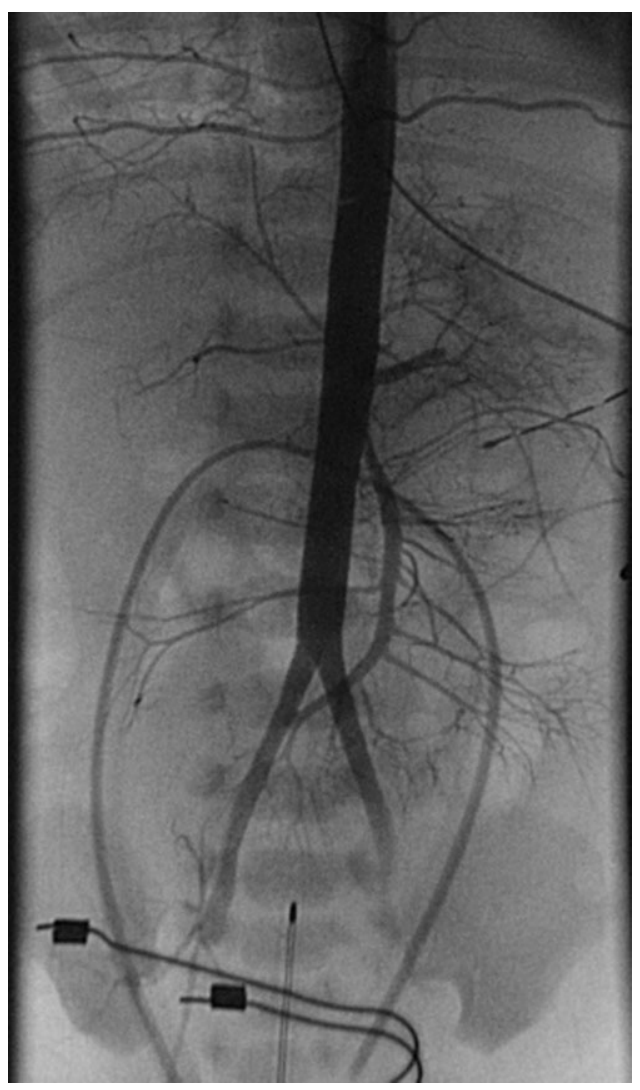

Fig. 4. After thrombectomy using the 6-Fr AngioJet catheter, repeat angiography was performed. All of the aortic thrombus was removed; the aorta had pulsatile flow; there was flow into the superior mesenteric, left renal and both common iliac arteries.

diagnosed his father with antithrombin III deficiency and his mother with Protein S deficiency.

\section{DISCUSSION}

Since spontaneous abdominal aortic thrombosis is rare in neonates and infants, the published reports is limited to case reports. Klinger et al. reviewed reports of abdominal aortic thrombosis in neonates from 1978 to 1999 [4]. Of these 63 patients, the thrombus was due to a UAC in $77 \%$ and a thrombophilic disorder in $8 \%$. Treatment included anticoagulation, thrombolytic agents, and surgery. Forty-two patients had resolution of thrombus, and 18 patients died. The neonates who survived had complications including hemorrhages and renal impairment, along with gastrointestinal, neurologic, and orthopedic problems. The 2008 guidelines for antithrombotic therapy in children recommended a trial of thrombolytic therapy or surgery if an infant presents with a spontaneous abdominal aortic thrombus that threatens the infant's life, limb, or organs [5]. 
The AngioJet ${ }^{\circledR}$ Thrombectomy catheter system was developed for use in adults to remove thrombus in small vessels [6,7]. The catheter, available in size 4 through $7 \mathrm{Fr}$, is connected to an external console unit, which produces powerful saline jets that travel down the catheter, then back at high speed. This creates a low pressure zone around the catheter tip, resulting in a powerful vacuum effect drawing thrombus into the catheter orifices, where it is fragmented by the jets, and removed from the body. Thrombolytic agents can be delivered into the thrombus just prior to the thrombectomy procedure.

In adult patients with peripheral vascular disease, the AngioJet ${ }^{\circledR}$ catheter removed acute and subacute arterial thrombi with blood flood restoration in $88-98 \%$ of cases [7]. Complications of this technique were not common but included bleeding (2-11\%), distal emboli $(6-10 \%)$, and perforation or dissection of the vessel $(2-4 \%)$. In coronary arteries, the success of the procedure was similar to peripheral vascular lesions [6]. The most common complications with coronary artery thrombectomy are bradycardia and heart block $[6,8,9]$. Bradycardia may be related to activation of vascular endothelium stretch receptors or adenosine release from red cell hemolysis $[9,10]$.

Although catheter thrombectomy is used frequently in adults, there are few reports describing its use in pediatric patients. The Angiojet ${ }^{\circledR}$ catheter has been used to remove thrombus from pulmonary arteries and aortopulmonary shunts in neonates and children [10-14]. A similar catheter, the X-SIZER ${ }^{\circledR}$ catheter system (eV3, Plymouth, MN), was used to treat a complete superior vena cava thrombus in a 4 year-old child following a Fontan operation [15]. The procedure was successful acutely, and follow-up angiography displayed further resolution of the thrombus. The X-SIZER ${ }^{\circledR}$ catheter is a self contained unit which does not require the external console unit, however, is does not create as powerful a vacuum effect as the AngioJet $^{\circledR}$ catheter.

In our critically ill neonate, anticoagulation, thrombolytic medications, and surgery were contraindicated. Catheter thrombectomy was performed, initially using the AngioJet ${ }^{\circledR}$ 4-Fr XMI ${ }^{\circledR}$ catheter, recommended for vessels 2-5 $\mathrm{mm}$ diameter, which seemed appropriate for the occlusive thrombus in this $5.4 \mathrm{~mm}$ diameter descending aorta. Since this catheter-afforded minimal improvement, it was exchanged for the AngioJet ${ }^{\circledR} 6 \mathrm{Fr}$ XPEEDIOR ${ }^{\circledR}$ catheter, which tracked easily over the 0.014-inch wire (it has a 0.035-inch wire lumen), and was much more effective in thrombus removal without additional complication; this catheter is recommended for thrombus removal in vessels 4-12 mm diameter. The thrombectomy procedure immediately restored aortic patency and blood flow to multiple organs and improved cardiac function. Due to the patient's small size, a blood transfusion was necessary to replace the blood volume removed by the AngioJet ${ }^{\circledR}$ catheters. Bradycardia, which occurred with each pass of the AngioJet ${ }^{\circledR}$ catheters, resolved without intervention, and it may be minimized (or prevented) using short duration catheter passes (7-10 s) or prophylactically administering atropine [13,14]. In addition, careful wire manipulation is necessary to prevent vessel wall dissection or perforation, which would be magnified by subsequent thrombectomy catheter manipulation.

Although the infant did not survive, due to intracranial venous thrombosis and hemorrhages, mechanical thrombectomy using the AngioJet ${ }^{\circledR}$ catheter thrombectomy was successful. The authors demonstrate that this technique is applicable to neonates and infants. The 4Fr catheter can be used through a femoral artery sheath, and the 4- or 6-Fr catheter can be used through a femoral vein sheath.

With the history of paternal antithrombin III deficiency and maternal protein $\mathrm{S}$ deficiency, an inherited thrombophilia is the most plausible explanation for this neonate's aortic thrombus, thalamic infarcts, intracranial hemorrhages, and multi-organ failure. However, the infant died before a complete hematology evaluation could be performed.

\section{CONCLUSION}

In a critically ill neonate, the AngioJet ${ }^{\circledR}$ thrombectomy catheter was successful in immediately removing an occlusive aortic thrombus without complication. The AngioJet ${ }^{\circledR}$ catheter is a therapeutic option for pediatric patients in whom it is preferable to avoid medical thrombolytic agents or surgical thrombectomy.

\section{REFERENCES}

1. Chalmers EA. Neonatal thrombus. J Clin Pathol 2000;53: 419-423.

2. Andrew ME, Monagle P, DeVeber G, Chan AK. Thromboembolic disease and antithrombotic therapy in newborns. Hematol Am Soc Hematol Educ Prog 2001:358-374.

3. Rodriguez M, Sosenko I. Catheter-induced aortic thrombus masquerading as coarctation of the aorta. Clin Pediatr 1989;28: $581-584$.

4. Klinger G, Hellmann J, Daneman A. Severe aortic thrombosis in the neonate-successful treatment with low-molecular-weight heparin: two case reports and review of the literature. Am J Perinatol 2000;17:151-158.

5. Monagle P, Chalmers E, Chan A, DeVeber G, Kirkham F, Massicotte P, Michelson AD;American College of Chest Physicians. Antithrombotic therapy in neonates and children: American College of Chest Physicians Evidence-Based Clinical Practice Guidelines (8th Ed). Chest 2008;133:887S-968S.

6. Lee MS, Singh V, Wilentz JR, Makkar RR. AngioJet thrombectomy. J Invasive Cardiol 2004;16:587-591. 
7. Dosluoglu HH, Harris LM. Endovascular management of subacute lower extremity ischemia. Semin Vasc Surg 2008;21:167-179.

8. Fontaine AB, Borsa JJ, Hoffer EK, Bloch RD, So CR, Newton M. Type III heart block with peripheral use of the AngioJet thrombectomy system. J Vasc Interv Radiol 2001;12:1223-1225.

9. Dwarka D, Schwartz SA, Smyth SH, O’Brien MJ. Bradyarrhythmias during use of the AngioJet System. J Vasc Interv Radiol 2006; 17:1693-1695.

10. Sur JP, Garg RK, Jolly N. Rheolytic percutaneous thrombectomy for acute pulmonary embolism in a pediatric patient. Catheter Cardiovasc Interv 2007;70:450-453.

11. Vincent RN, Dinkins J, Dobbs MC. Mechanical thrombectomy using the AngioJet in a child with congenital heart disease. Catheter Cardiovasc Interv 2004;61:253-255.
12. Fleming GA, Khan M, Janssen D, Doyle T. Angiojet rheolytic thrombectomy in infants following cardiac surgery. Catheter Cardiovasc Interv 2010;76:233-240.

13. Feldman JP, Feinstein JA, Lamberti JJ, Perry SB. Angiojet catheter-based thrombectomy in a neonate with postoperative pulmonary embolism. Catheter Cardiovasc Interv 2005;66:442-445.

14. Menon SC, Hagler DJ, Cetta F, Cabalka AK. Rheolytic Mechanical thrombectomy for pulmonary artery thrombus in children with complex cyanotic congenital heart disease. Catheter Cardiovasc Interv 2005;71:237-243.

15. Gossett JG, Rocchini AP, Armstrong AK. Superior vena cava thrombectomy with the X-SIZER catheter system in a child with Fontan palliation. Catheter Cardiovasc Interv 2007;69: $28-32$. 